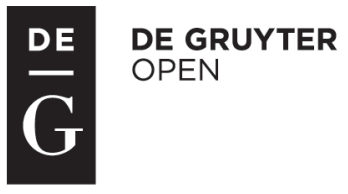

\title{
ANALYSIS OF PROLACTIN AND KAPPA-CASEIN GENES POLYMORPHISM IN FOUR CATTLE BREEDS IN TURKEY
}

\author{
Bilal Akyüz ${ }^{1 *}$, Mehmet Ulaş Çınar ${ }^{2}$ \\ ${ }^{1}$ Department of Genetics, Faculty of Veterinary Medicine, ${ }^{2}$ Department of Animal Science, \\ Faculty of Agriculture, Unit of Biometry and Genetics, \\ Erciyes University, 38039 Kayseri, Turkey \\ •Corresponding author: bakyuz@erciyes.edu.tr
}

\begin{abstract}
The objective of this study was to identify allele and genotype frequencies of CSN3 and PRL genes in four cattle breeds in Turkey. For this purpose, a total of 390 cattle of East Anatolian Red (EAR), Zavot, Brown Swiss (BS) and Simmental (SIM) breeds were genotyped by PCR-RFLP method. A 443 bp fragment of CSN3 and a 156 bp fragment of PRL were amplified and digested with HindIII and RsaI restriction enzymes, respectively. For CSN3 and PRL genes, two types of alleles ( $A$ and $B$ ) and three types of genotypes $(\mathrm{AA}, \mathrm{BB}$, and $\mathrm{AB})$ were observed. The highest frequencies for CSN3-A and CSN3-B alleles were estimated for the EAR breed (0.743) and for the BS breed (0.556), respectively. The highest frequency for PRL-A and PRL-B alleles was estimated for the SIM breed ( 0.801$)$ and for the BS breed $(0.315)$, respectively. The Chi-square test among the investigated cattle breeds showed that only the Zavot breed was in Hardy-Weinberg equilibrium (HWE) for both loci.
\end{abstract}

Key words: gene polymorphism, kappa-casein, local cattle breed, prolactin

In recent years, maintaining the genetic diversity of native farm animals has become an important issue for livestock production (Č́itek et al., 2006). The main aim of protecting native animal breeds is to preserve the unique genes in native breeds. These genes may have an association with economic or production traits such as disease resistance, longevity or fertility. Therefore, examination of possible candidate genes such as the prolactin (PRL) and kappa-casein (CSN3) genes, which are associated with production traits, could be important for native cattle breeds.

The prolactin hormone is an essential regulator of mammary gland development, lactogenesis (Brym et al., 2005) and milk protein synthesis in cattle (Sodhi et al., 2011). Therefore, PRL gene polymorphism can be considered as a potential genetic marker for milk productivity in cattle breeding (Khatami et al., 2005). The bovine PRL gene was mapped on chromosome 23, and consists of five exons and four in- 
trons (Alipanah et al., 2007). A polymorphism (A-G mutation) was detected at the fourth exon of the bovine PRL gene, which leads to the formation of a new restriction site for RsaI; this may serve as an informative molecular marker for milk yield and milk composition and be used to determine the genetic relationship among cattle breeds (Sodhi et al., 2011).

Casein is divided into four important groups as follows: $\alpha$ s1-casein (CSN1S1), as2-casein (CSN1S2), $\kappa$-casein (CSN3) and $\beta$-casein (CSN2) (Sulimova et al., 2007). The CSN3 gene was mapped to chromosome 6 of cattle and 12 variants of the CSN3 gene have been determined in cattle (Sulimova et al., 2007). However, the CSN3 gene has two common variants, $\mathrm{A}$ and $\mathrm{B}$. The A allele has a threonine (ACC) and aspartic acid (GAT) at positions 136 and 148, while the B allele has an isoleucine (ATC) and alanine (GCT) at the same positions (Patel et al., 2007). The relationships between different CSN3 variants with milk yield and the manufacturing properties of milk were explained by different researchers (Chrenek et al., 2003; Ceriotti et al., 2004; Lazebnaya et al., 2010). Additionally, genetic variability in the CSN3 gene is currently being used as an aid to investigate the genetic diversity and the genetic characterization of cattle breeds (Lara et al., 2002).

The Zavot breed has been bred for more than 150 years in the Kars and Ardahan provinces which are located in the northeast of Turkey. This breed was developed by crossbreeding the Simmental (SIM), Brown Swiss (BS) and native East Anatolian Red (EAR) cattle breeds (Yüksel et al., 2011). The milk and meat yield of the Zavot breed is higher than that of EAR cattle, which is another native cattle breed of Turkey (Aksoy et al., 2006).

To the best of our knowledge there is no data about the allelic distribution of CSN3 and PRL gene polymorphism in the Zavot cattle breed. The objective of this study was to determine the genotype and allelic frequency of CSN3 and PRL genes in the Zavot, EAR, BS and SIM cattle breeds.

\section{Material and methods}

\section{DNA materials}

In this study, the EAR ( $\mathrm{n}=74$, from Erzurum and Kars), SIM ( $\mathrm{n}=108$, from Kayseri, Nevşehir, Kırşehir and Yozgat), BS ( $n=108$, from Ankara, Kayseri, Nevşehir and Yozgat) and Zavot ( $\mathrm{n}=100$, from Ardahan and Kars) breeds were investigated. DNA was isolated from the whole blood of 390 animals by using the phenol-chloroform procedure (Sambrook et al., 1989).

\section{PCR and genotyping}

CSN3 specific primers (forward 5'-gctgagcaggtatcctagttat-3'; reverse 5'-cttctttgatgtctccttagag-3') and PRL specific primers (forward 5'-cgagtccttatgagcttgattctt-3'; reverse 5'-gccttccagaagtcgtttgttttc-3') were used to amplify the $453 \mathrm{bp}$ and $156 \mathrm{bp}$ fragments, respectively (Chrenek et al., 2001). 
PCR reactions for the CSN3 and PRL genes consisted of $100 \mathrm{ng}$ of genomic DNA in a standard PCR buffer with $1.5 \mathrm{mM} \mathrm{MgCl}_{2}, 200 \mu \mathrm{M}$ of each dNTPs, 5 pmol of each primer and $1 \mathrm{U}$ Taq DNA polymerase in $25 \mu \mathrm{l}$ reaction. The PCR reaction for CSN3 included the following steps: initial denaturation for 4 minutes at $95^{\circ} \mathrm{C}$ followed by 35 cycles of $95^{\circ} \mathrm{C}$ ( 40 seconds), $53^{\circ} \mathrm{C}$ ( 40 seconds), $72^{\circ} \mathrm{C}$ ( 40 seconds) and a final extension step of 5 minutes at $72^{\circ} \mathrm{C}$. For the PRL gene, the PCR reaction included the following steps: initial denaturation for 4 minutes at $94^{\circ} \mathrm{C}$, followed by 40 cycles of $94^{\circ} \mathrm{C}$ (30 seconds), $55^{\circ} \mathrm{C}(30$ seconds $)$ and $72^{\circ} \mathrm{C}(30$ seconds $)$ and the final extension step of 10 minutes at $72^{\circ} \mathrm{C}$. The amplified PCR products of CSN3 were digested with 10 units of HindIII restriction enzyme (Fermentas) and $1 \times$ reaction buffer at $37^{\circ} \mathrm{C}$ for 4 hours. The amplified PCR products of PRL were digested with 10 units of $R s a \mathrm{I}$ restriction enzyme (Fermentas) and $1 \times$ reaction buffer at $37^{\circ} \mathrm{C}$ for 3 hours. The digestion products of the CSN3 and PRL genes were separated by $3 \%$ agarose gel electrophoresis.

\section{Statistical analysis}

Hardy-Weinberg equilibrium (HWE) was checked by using the Chi-square statistic $\left(\chi^{2}\right)$. All statistical analyses were performed using PopGene32 package version 1.31 (Yeh et al., 2000).

\section{Results}

The genetic polymorphism in the CSN3 locus was investigated by digestion of the PCR product with HindIII restriction endonuclease. In this study, two alleles were detected, namely the A and B alleles, in the CSN3 locus. In addition, three genotypes were identified for the $\mathrm{CSN} 3$ gene (AA, AB and $\mathrm{BB}$ ) in the examined cattle breeds. After digestion of HindIII, two fragments were expected to be seen for the $\mathrm{BB}$ genotype (348 and $95 \mathrm{bp}$ ), three fragments were expected to be seen for the $\mathrm{AB}$ genotype (443, 348 and $95 \mathrm{bp}$ ) and a single undigested fragment was obtained for the AA genotype (443 bp). However, since 443 and 348 bp bands were clearly seen together and separately, it was thought that genotyping was successfully fulfilled without observing 95 bp band (Figure 1).

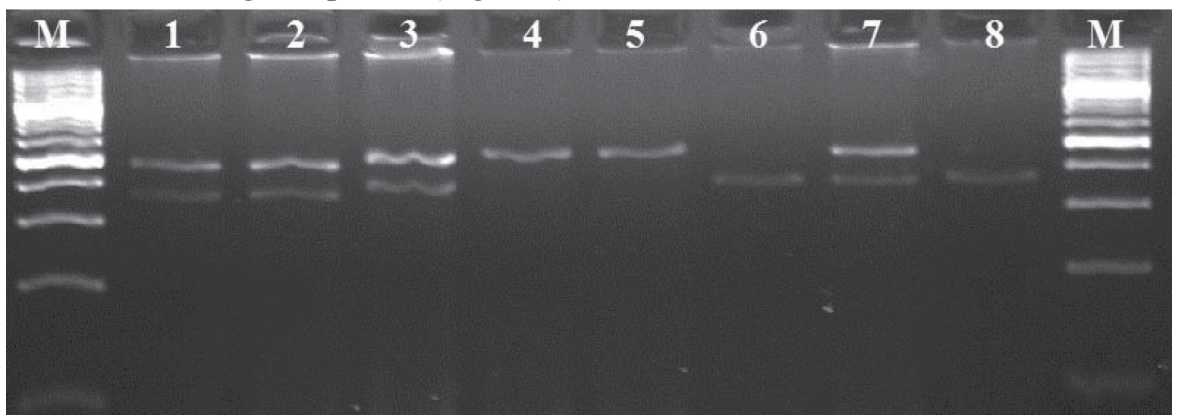

Figure 1. CSN3 genotyping with PCR-RFLP method. M: DNA marker (100 bp); Lanes 4 and 5: AA genotypes; Lanes 6 and 8: BB genotypes; Lanes 1-3 and 7: AB genotypes 
The highest frequency of the CSN3-A allele was observed in EAR cattle (0.743) and the highest frequency of the CSN3-B allele was found in BS cattle (0.556). The highest AA genotypic frequency was determined in the EAR breed (0.527); the highest BB genotypic frequency was found in the BS breed (0.252) and the AB genotypic frequency was found to be highest in the BS breed (0.608) in CSN3. The observed heterozygosity varied from 0.342 to 0.607 for the CSN3 gene in the four examined cattle breeds. The observed heterozygosity, the expected heterozygosity and the gene frequencies for CSN3 in the studied cattle breeds are shown in Table 1. The deviation from HWE was not detected in the EAR and Zavot breeds, while it was detected in the SIM and BS breeds for the CSN3 gene (Table 1).

Table 1. Heterozygosity, allele and genotype frequencies of CSN3 gene in EAR, SIM, BS and Zavot breeds

\begin{tabular}{l|r|c|c|c|c|c|c|c|c|l}
\hline & & \multicolumn{3}{|c|}{ Genotype frequency } & \multicolumn{2}{c|}{ Allele frequency } & \multicolumn{2}{c|}{ Heterozygosity } & \multirow{2}{*}{$\chi^{2}$} & \multirow{2}{*}{ P-value } \\
\cline { 1 - 9 } Breeds & $\mathrm{n}$ & $\mathrm{AA}$ & $\mathrm{BB}$ & $\mathrm{AB}$ & $\mathrm{A}$ & $\mathrm{B}$ & $\mathrm{H}_{\mathrm{E}}$ & $\mathrm{H}_{\mathrm{O}}$ & & \\
\hline EAR & 74 & 0.527 & 0.041 & 0.432 & 0.743 & 0.257 & 0.384 & 0.432 & 1.188 & $0.275 \mathrm{NS}$ \\
Zavot & 100 & 0.400 & 0.100 & 0.500 & 0.650 & 0.350 & 0.457 & 0.500 & 0.883 & $0.347 \mathrm{NS}$ \\
SIM & 108 & 0.500 & 0.157 & 0.343 & 0.671 & 0.329 & 0.443 & 0.342 & 5.645 & $0.017^{*}$ \\
BS & 10 & 0.140 & 0.252 & 0.608 & 0.444 & 0.556 & 0.496 & 0.607 & 5.453 & $0.019^{*}$ \\
\hline
\end{tabular}

$\mathrm{NS}$ - non significant, * - significant $(\mathrm{P}<0.05), \mathrm{H}_{\mathrm{E}}$ - Expected Heterozygosity, $\mathrm{H}_{\mathrm{O}}$ - Observed Heterozygosity.

Detection of the genetic polymorphism of the PRL gene was performed by digestion of the PCR products of $156 \mathrm{bp}$ with $R s a \mathrm{I}$ restriction enzyme. The enzyme did not digest the PCR product for the AA genotype while enzyme digested the PCR product into two fragments of 82 and $74 \mathrm{bp}$ for the BB genotype. In addition, heterozygotes $\mathrm{AB}$ were obtained in three fragments of 156,82 and $74 \mathrm{bp}$ (Figure 2).

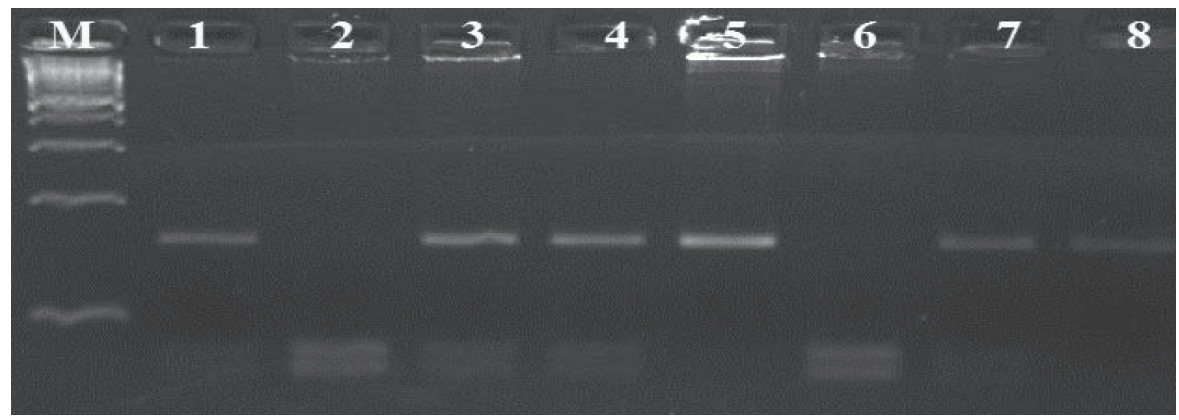

Figure 2. PRL genotyping with PCR-RFLP method. M: DNA markers (100 bp); Lanes 5 and 8: AA genotypes; Lanes 2 and 6: BB genotypes; Lanes 1, 3, 4 and 7: AB genotypes

The frequency distribution of the PRL-A allele was the highest among the breeds investigated, ranging from 0.685 (BS) to 0.801 (SIM). PRL-B allele frequency was found to be lower in the four breeds. In this study, three genotypes were obtained (Figure 2). The AA genotype was the most frequent in the EAR (0.635) and SIM 
(0.630) breeds whereas the BB genotype was the least frequent in each of the four cattle breeds. The observed heterozygosity varied from 0.202 to 0.481 for the PRL gene in the studied cattle breeds. The observed heterozygosity, expected heterozygosity, and estimated gene frequencies for the PRL gene are given in Table 2 for the studied cattle breeds. The deviation from HWE was detected in the EAR breed, while the SIM, BS and Zavot breeds were in HWE for the PRL gene.

Table 2. Heterozygosity, allele and genotype frequency of PRL (A and B alleles) in EAR, SIM, BS and Zavot breeds

\begin{tabular}{|c|c|c|c|c|c|c|c|c|c|c|}
\hline \multirow[b]{2}{*}{ Breeds } & & \multicolumn{3}{|c|}{ Genotype frequency } & \multicolumn{2}{|c|}{ Allele frequency } & \multicolumn{2}{|c|}{ Heterozygosity } & \multirow{2}{*}{$\chi^{2}$} & \multirow{2}{*}{ P-value } \\
\hline & & $\mathrm{AA}$ & $\mathrm{BB}$ & $\mathrm{AB}$ & $\mathrm{A}$ & $\mathrm{B}$ & $\mathrm{H}_{\mathrm{E}}$ & $\mathrm{H}_{\mathrm{O}}$ & & \\
\hline EAR & 74 & 0.635 & 0.162 & 0.203 & 0.737 & 0.263 & 0.390 & 0.202 & 17.516 & $0.000 *$ \\
\hline Zavot & 100 & 0.530 & 0.100 & 0.370 & 0.715 & 0.285 & 0.409 & 0.370 & 0.948 & $0.330 \mathrm{NS}$ \\
\hline SIM & 108 & 0.630 & 0.027 & 0.343 & 0.801 & 0.199 & 0.320 & 0.342 & 0.530 & $0.466 \mathrm{NS}$ \\
\hline BS & 108 & 0.444 & 0.074 & 0.482 & 0.685 & 0.315 & 0.433 & 0.481 & 1.344 & $0.246 \mathrm{NS}$ \\
\hline
\end{tabular}

$\mathrm{NS}$ - non significant, * - significant $(\mathrm{P}<0.05), \mathrm{H}_{\mathrm{E}}-$ Expected Heterozygosity, $\mathrm{H}_{\mathrm{O}}-$ Observed Heterozygosity.

\section{Discussion}

In livestock breeding, some genes are proposed as potential candidates for quantitative traits that enhance economic values such as fertility, milk yield and meat production (Lara et al., 2002). Among the various candidate genes, CSN3 and PRL appear to be promising for such economic traits (Khatami et al., 2005; Otaviano et al., 2005). Therefore, the relationship between the allelic variations of the CSN3 and PRL genes and milk yield traits has been examined in different cattle breeds (Chrenek et al., 2003; Tsiaras et al., 2005; Lazebnaya et al., 2010).

The allele and genotype distribution of CSN3 gene was investigated by different researchers (Lara et al., 2002; Chrenek et al., 2003; Patel et al., 2007; Sulimova et al., 2007; Dogru and Ozdemir, 2009). The frequency of the CSN3-B allele was found to be higher than the frequency of A allele in the BS breed (Caroli et al., 2004; Dogru and Ozdemir, 2009). Similarly, in our study the frequency of the CSN3-B allele was found to be highest in the BS breed (0.556). Sulimova et al. (2007) found that the frequency of the CSN3-A allele was found to be higher than the frequency of B allele in SIM breed. However, our study revealed that frequencies of CSN3-A and B alleles were found to be close to each other in the SIM and Zavot breeds (Table 1). Additionally, in Turkish native cattle breeds, the frequency of the CSN3-A allele was found to be highest in the EAR breed (0.761) (Dinc et al., 2011; Akyuz et al., 2012). Overlapping with our results, the frequency of the CSN3-A allele was found to be highest in the EAR breed $(0.743)$ when compared with the other breeds in this study.

The CSN3 genotypes were reported to have favourable and significant effects on milk yield, milk content, milk technological properties and cheese yield (Chrenek et al., 2003; Alipanah et al., 2007; Tsiaras et al., 2005; Wedholm et al., 2006). Tsiaras 
et al. (2005) found that allele A has a tendency for increased milk and fat yield of the Holstein cattle. In our study the frequency of A allele was found to be higher compared to B allele in Turkish native cattle breeds (Table 1). On the other hand, similar to our results Chrenek et al. (2003) found that the frequency of B allele was more abundant compared to A allele in the BS breed. Additionally, they observed that genotype $\mathrm{BB}$ was significantly associated with better milk production traits. The positive effects of $\mathrm{B}$ allele in cheese yielding capacity and milk productivity was mentioned by Sulimova et al. (2007), who stated that the cheese yield was $10 \%$ higher in Russian native cows that have BB genotype. Dobicki et al. (2002) investigated the association between CSN3 variants and milk properties in the cattle breeds Red and White, Charolais and their crossbreed. Although they found no association between genotypes and phenotypes, they observed that CSN3 BB genotype tended to have higher milk yield index in suckling cows and higher weight gain in the calves.

Variation in PRL gene was studied by different researchers (Chrenek et al., 2003; Brym et al., 2005; Dybus et al., 2005; Khatami et al., 2005; Sodhi et al., 2011). The frequency of the PRL-A allele (0.61) was found to be higher than B allele frequency in the BS breed (Chrenek et al., 2003). Additionally, PRL-A allele frequency was found to be higher than B allele frequency in Polish Red, Czech Red, German Red and Yakutian cattle breeds (Zatoń-Dobrowolska et al., 2007; Lazebnaya et al., 2010). Moreover, the PRL-A allele was accepted as predominant in cattle breeds which originate from Bos taurus (Sodhi et al., 2011). Similarly, PRL-A allele frequency was found to be higher than B allele frequency in all breeds which are investigated in this study (Table 2).

There are several studies which investigated the relationship between PRL genotypes and milk productivity parameters in dairy cattle (Brym et al., 2005; Dybus et al., 2005; Alipanah et al., 2007). Among them, Alipanah et al. (2007) found significant association between PRL genotypes and milk production traits in Russian Red Pied cattle. They found that genotype BB showed higher milk fat yield compared to other genotypes. Although B allele exists in Turkish cattle breeds investigated in this study, the frequency of B allele and BB genotype was lower (Table 2). PRL genotypes showed significant association with the fat content in Jersey breed in a study by Dybus et al. (2005), who found that genotypes AB and BB had produced more fat compared to genotype AA. In our study genotype AA was found to be the most abundant genotype except BS breed (Table 2). Brym et al. (2005) investigated the PRL association with milk yield in Black and White cows by using a different SNP than that used for our study. They found that genotype AG showed the highest milk yield, however the genotype GG showed the highest milk fat content.

In this study, the Zavot breed and three other breeds (EAR, SIM and BS) that contributed to the formation of the Zavot breed were examined in order to investigate the allele and genotype frequencies of CSN3 and PRL genes. To the best of our knowledge this is the first report on the genetic variation of CSN3 and PRL genes in Zavot breed. Survival of Zavot and EAR breeds is important for local cattle breeders for their outstanding adaptability to native environmental conditions. Since this study showed the existence of both alleles in the Zavot population, in the light of our results it can be speculated that genetic selection based on favourable allele may 
increase the milk production traits of this cattle breed. Further study is required to examine the association between yield traits and genotypes.

\section{Acknowledgements}

Authors are indebted to Dr. Özgecan Korkmaz Ağaoğlu for her contribution to the manuscript.

\section{References}

A k s o y A.R., K ir m i z ib a y ra k T., S a a t c i M. (2006). The effect of age on slaughter and carcass characteristics in male Zavot cattle. Turk. J. Vet. Anim. Sci., 30: 527-532.

A k y u z B., A g a o g 1 u O.K., E r t u g r u 1 O. (2012). Genetic polymorphism of kappa-casein, growth hormone and prolactin genes in Turkish native cattle breeds. Int. J. Dairy Technol., 65: 38-44.

Alipanah M., Kalashnikova L.N.D., Rodionov G. (2007). Association of prolactin gene variants with milk production traits in Russian Red Pied cattle. Iran. J. Biotech., 5: 158-161.

B ry m P., Ka mińs ki S., Wójcik E. (2005). Nucleotide sequence polymorphism within exon 4 of the bovine prolactin gene and its associations with milk performance traits. J. Appl. Genet., 45: $179-185$.

Caroli A., Ches s a S., B olla P., B u de 11 i E., G an d in i G.C. (2004). Genetic structure of milk protein polymorphisms and effects on milk production traits in a local dairy cattle. J. Anim. Breed. Genet., 121: 119-127.

Ceriotti G., Marlett a D., Caroli A., Erhard t G. (2004). Milk protein loci polymorphism in taurine (Bos taurus) and zebu (Bos indicus) populations bred in hot climate. J. Anim. Breed. Genet., 121: 404-415.

Chrenek P., Boulanger L., Heyman Y., Uhrin P., Laurincik J., Bulla J., Re$\mathrm{n}$ ard J-P. (2001). Sexing and multiple genotype analysis from a single cell of bovine embryo. Theriogenology, 55: 1071-1081.

Chrenek P., H uba J., Vasicek D., Peskovicová D., B ulla J. (2003). The relation between genetic polymorphism markers and milk yield in Brown Swiss cattle imported to Slovakia. Asian Austral. J. Anim., 16: 1397-1401.

Čítek J., Panicke L., Řehout V., Procházková H. (2006). Study of genetic distances between cattle breeds of Central Europe. Czech J. Anim. Sci., 51: 429-436.

D in c H., O z k a n E., K o b a n E., To g a n I. (2011). From milk protein polymorphisms to breeding practices in Turkey. Proc. 8th Annual Meeting of RBI Global Conference on the Conservation of Animal Genetic Resources, Tekirdag, Turkiye, 4-8.10.2011.

Dobicki A., Chládek G., Z a chwieja A. (2002). Growth rate of calves and condition of their Red-and-White, Charolais, F1 or R1 dams in relation to the genetic polymorphism of milk proteins. Anim. Sci. Pap. Rep., 20 (Suppl 1): 161-167.

D o g r u U., O z d e m ir M. (2009). Genotyping of kappa-casein locus by PCR-RFLP in Brown Swiss cattle breed. J. Anim. Vet. Adv., 8: 779-781.

Dybus A., Grzesiak W., Kamieniecki H., Szatkowska I., S obek Z., Błaszczyk P., Czerniawska-Piątkowska E., Zych S., Muszyńska M. (2005). Association of genetic variants of bovine prolactin with milk production traits of Black-and-White and Jersey cattle. Arch. Tierzucht, 48: 149-156.

Kh a tami S.R., La ze bny O.E., Maks imenko V.F., S u li mova G.E. (2005). Association of DNA polymorphisms of the growth hormone and prolactin genes with milk productivity in Yaroslavl and Black-and-White cattle. Russ. J. Genet., 41: 167-173.

L ar a M.A.C., G a m a L.T., B u far a h G., S er e no J.R.B., C e 1 e g a to E.M.L., d e A bre u U.P. (2002). Genetic polymorphisms at the א-casein locus in Pantaneiro cattle. Archivos de Zootecnia, 51: 99-105.

L a z e b n a y a I.V., L a z e b n y O.E., S u 1 i m o va G.E. (2010). Study of genetic variation in Yakutian cattle (Bos taurus L.) using the prolactin bPRL, growth hormone bGH, and transcription factor bPit-1 genes. Russ. J. Genet., 46: 377-380. 
O t a vi a n o A.R., To n h a t H., S e n a J.A.D., M uñ o z M.F.C. (2005). Kappa-casein gene study with molecular markers in female buffaloes (Bubalus bubalis). Genet. Mol. Biol., 28: 237-241.

Pat el R.K., Chauhan J.B., S ingh K.M., S on i K.J. (2007). Allelic frequency of kappa-casein and beta-lactoglobulin in Indian crossbred (Bos taurus $\times$ Bos indicus) dairy bulls. Turk. J. Vet. Anim. Sci., 31: 399-402.

S a mbrook J., Frits ch E.F., Maniat is T. (1989). Molecular Cloning: A Laboratory Manual, 2 ed., 3 vol., Cold Spring Harbor Laboratory, Cold-Spring Harbor, New York.

Sodhi M., Mukesh M., Mishra B.P., Parvesh K., Joshi B.K. (2011). Analysis of genetic variation at the prolactin-RsaI (PRL-RsaI) locus in Indian native cattle breeds (Bos indicus). Biochem. Genet., 49: 39-45.

Suli mova G.E., Azari M.A., Rost a mzadeh J., Abani M.R.M., Lazebny O.E. (2007). $\kappa$-casein gene (CSN3) in Russian cattle breeds and its informative value as a genetic marker. Russ. J. Genet., 43: 73-79.

Ts i ar a s.M., B argouli G.G., B a nos G., B os cos C.M. (2005). Effect of kappa-casein and beta-lactoglobulin loci on milk production traits and reproductive performance of Holstein cows. J. Dairy Sci., 88: 327-334.

Wedholm A., Larsen L.B., Lindmark-Måns son H., Karls son A.H., Andrén A. (2006). Effect of protein composition on the cheese-making properties of milk from individual dairy cows. J. Dairy Sci., 89: 3296-3305.

Yeh F., Yang R.C., B o y le T. (2010). 2000. Popgene (v.1.32), Microsoft Windows-Based Freeware for Population Genetic Analysis, Retrieved 31 August, from http:// www.ualberta.ca/ fyeh/Pop32. exe.

Y üksel S., Sezg in E., K opuzlu S. (2011). One of the native animal genetic resources and its importance in animal husbandry: Zavot cattle. RBI 8th Global Conference on the Conservation of Animal Genetic Resources, Tekirdag, Turkey, 4-8.10.2010, pp. 193-197.

Zatoń-Dobrowolska M., Čitek J., Filistowicz A., Ǩ ehout V., Szulc T. (2007). Genetic distance between the Polish Red, Czech Red and German Red cattle estimated based on selected loci of protein coding genes and DNA microsatellite sequences. Anim. Sci. Pap. Rep., 25: 45-54.

Received: 25 X 2013

Accepted: 19 III 2014 